\title{
Effect of water stress on the growth of Arachis pintoi plants under different nitrogen levels
}

\section{Rita Manuele Porto Sales ${ }^{1}$, Daniela Deitos Fries², Paulo Bonomo², Aureliano José Vieira Pires ${ }^{3}$, Cleide Nascimento Campos ${ }^{4}$, Paulo Henrique Rodrigues Brito ${ }^{4}$, Iracema Souza Pereira ${ }^{4}$, Joelma da Silva Santos ${ }^{4}$}

\author{
${ }^{1}$ Mestranda em Zootecnia/UESB, Itapetinga, BA, Brazil. \\ ${ }^{2}$ Departamento de Estudos Básicos e Instrumentais/UESB, Itapetinga, BA, Brazil. \\ ${ }^{3}$ Departamento de Tecnologia Rural e Animal/ UESB, Itapetinga, BA, Brazil. Researcher at CNPq. \\ ${ }^{4}$ Graduando em Ciências Biológicas/UESB, Itapetinga, BA, Brazil.
}

\begin{abstract}
The objective was to evaluate the growth of Arachis pintoi fertilized with nitrogen and water deficiency conditions. The study was developed in a $4 \times 4$ factorial arrangement with four nitrogen levels $(0,40,80$ and $120 \mathrm{~kg} \mathrm{~N} / \mathrm{ha})$ and four irrigation levels $(25,50,75$ and $100 \%$ of field capacity), in a completely randomized experimental design, with four replications. High doses of $\mathrm{N}$ benefited the production of root shoots while the root increased its production at a dose of $40 \mathrm{~kg}$ $\mathrm{N} / \mathrm{ha}$. The number of green and senescent leaves were influenced by $\mathrm{N}$ fertilization and the water regime, where higher doses of $\mathrm{N}$ provided greater total number of green leaves (364 leaves/pot) and the limitation of water resulted in a greater number of senescent leaves (78 leaves/pot). Observing the maximum point, the water regime of $90 \%$ of field capacity and $120 \mathrm{~kg} \mathrm{~N} / \mathrm{ha}$ favored leaf appearance rate of 1.2 leaves/day and less phyllochron (4.6 days/leaf) at 85\% of field capacity and $115 \mathrm{~kg} \mathrm{~N} / \mathrm{ha}$. The dose of $120 \mathrm{~kg} \mathrm{~N} /$ ha resulted in ultimate greater width $(1.4 \mathrm{~cm})$ and length $(2.4 \mathrm{~cm})$ of the leaf at $100 \%$ of field capacity. The final length of stolons showed quadratic effect for N, having greatest length $(58.1 \mathrm{~cm})$ at $75 \mathrm{~kg} \mathrm{~N} / \mathrm{ha}$ and $100 \%$ of field capacity.
\end{abstract}

Key Words: legume, morphogenesis, root, water

\section{Introduction}

Leguminous plants have been extensively studied in an attempt to obtain a low-cost, balanced, sustainable and ecologically correct animal farming (Silva, 2008). In the South of Bahia State, Brazil, Arachis pintoi cv. is a plant that stands out for its rusticity, nutritional quality and vegetative soil cover, promoting recovery of degraded pasture areas, in addition to its great adaptation to low-fertility soils and capacity of vegetative production and multiplication through stolons (Pizarro \& Rincón, 1994).

One of the greatest contributions of Arachis to the production system, like any other legume, is its potential to fix atmospheric nitrogen, resulting in forage of better nutritional quality and improvement of soil fertility (Miranda et al., 2003).

According to Ramos et al. (2010), the establishment of forage peanut can be considered quite slow, which is one of the main limitations of the species, depending on the soil fertility, water regime, mode of propagation and propagule density. In leguminous plants, when performed in big quantities, nitrogen fertilization can interfere in the formation of nodes, and consequently in the biological nitrogen fixation. Evaluating the interference of nitrogen in productivity and nodulation of soy, Mendes et al. (2008) concluded that in spite of showing crop yield, the application of $200 \mathrm{~kg} \mathrm{~N} / \mathrm{ha}$ impaired nodulation.

Nitrogen is a constituent of important cell components such as chlorophyll, proteins and nucleic acids that is required at big amounts and limits plant growth (Taiz \& Zeiger, 2009). Once the basic nutrient requirements are met, it is the nitrogen that determines the speed of growth and production of forage (Silva, 2008).

Another limiting factor to forage growth is water availability. The exposure of plants to water limitation in the environment brings about several physiological changes, and some plants show a few mechanisms of tolerance to drought such as diminution of the leaf area, leaf abscission and elevated root growth (Taiz \& Zeiger, 2009). According to Pompeu et al. (2010), with elevation of $\mathrm{N}$ in the soil, there is greater water absorption by the roots, increasing the water demand of plants generated by greater leaf production.

There are few studies on physiology and adaptation of forage legumes to water stress and on the presence of nitrogen in the soil. Inasmuch as nitrogen is the determinant 
factor in biomass production in the plant after the other nutritional requirements are met, its study related to water deficiency is therefore necessary.

Studying the growth of forage peanut under water deficiency conditions, the objective of this experiment was to evaluate the effect of water stress on the growth of Arachis pintoi cv. Belmonte cultivated under different nitrogen doses.

\section{Material and Methods}

The experiment was conducted in a greenhouse in the Laboratory of Forage and Pasture of Universidade Estadual do Sudoeste da Bahia, UESB, Campus Juvino Oliveira, in the municipality of Itapetinga-BA, Brazil, in the period from July to October 2010. The trial was conducted in a $4 \times 4$ factorial arrangement, which consisted of four nitrogen doses $(0,40,80$ and $120 \mathrm{~kg} / \mathrm{ha})$ and four water regimes $(25,50,75$ and $100 \%$ of field capacity (FC)), set in a completely randomized design with four replications, totaling 64 plastic pots with capacity of $10 \mathrm{dm}^{-3}$.

The soil utilized was classified as an Orthic Quartzarenic Neosol of sandy loam texture according to the protocol of soil analysis, collected at $0-20 \mathrm{~cm}$ depth on the campus of Universidade Estadual do Sudeste da Bahia, UESB. After passing through a $4 \mathrm{~mm}$ mesh sieve, the vase was filled and the material for the analysis of the ground was collected. The soil chemical analysis, performed at the Department of Agricultural Engineering and Soil Science of UESB, presented the following characteristics: $\mathrm{pH}$ in water $=5.7$; $\mathrm{P}=37 \mathrm{mg} / \mathrm{dm}^{3}$, in Mehlich extractant; $\mathrm{K}=0.30 \mathrm{cmol}_{\mathrm{c}} / \mathrm{dm}^{3}$; $\mathrm{Ca}^{2+}=3.0 \mathrm{cmol}_{\mathrm{c}} / \mathrm{dm}^{3} ; \mathrm{Mg}^{2+}=1.4 \mathrm{cmol}_{\mathrm{c}} / \mathrm{dm}^{3} ; \mathrm{Al}=0.1 \mathrm{cmol}_{\mathrm{c}} \mathrm{dm}^{3}$; $\mathrm{H}=2.1 \mathrm{cmol}_{\mathrm{c}} / \mathrm{dm}^{3}$; base saturation $=4.7 \mathrm{cmol}_{\mathrm{c}} / \mathrm{dm}^{3} ; \mathrm{T}=$ $6.9 \mathrm{cmol}_{\mathrm{c}} / \mathrm{dm}^{3} ; \mathrm{V}=68 \%$; and organic matter $=29 \mathrm{~g} / \mathrm{dm}^{3}$.

According to the recommendations of Comissão de Fertilidade do Solo do Estado de Minas Gerais (Alvarez \& Ribeiro, 1999), there was no need for liming, once the base saturation value was at $68 \%$ in the soil layer collected. Because the legumes were classified, by the same authors, as of medium technological level, the $\mathrm{P}$ and $\mathrm{K}$ values were also adequate, with no need for correction.

Nitrogen levels $(0,40,80$ and $120 \mathrm{~kg} / \mathrm{ha}$, corresponding to urea levels of $0.44,0.89$ and $1.33 \mathrm{~g} /$ pot) were divided in two applications: the first was performed on the day the cuttings were planted, and the second 20 days after.

Seedlings of Arachis pintoi cv. Belmonte were produced from stolons of mother plants obtained in Campus Juvino Oliveira. The planting of cuttings, with a node, was conducted on July 21, 2010, and after shooting, plants were thinned so as to keep four plants per pot.
For the determination of field capacity, pots with dry soil were weighed, soaked, and after total drain of the water, weighed again. Maximum water holding capacity (approximately 20\%) was determined by the difference between dry and soaked soil weights. The determination of water refill for all field capacity was calculated in relation to this difference. To maintain the soil close to the field capacity in the different water regimes, all pots were weighed and adjusted at every two days. During this initial growth phase, seedlings were kept close to field capacity, with different water regimes applied after 70 days.

After the growth period, plants were subjected to the water regimes of $25,50,75$ and $100 \%$ of the soil field capacity, and growth was assessed for a period of 15 days, determined by the senescence of plants subjected to the regime of $25 \%$ field capacity. After this period, pots were disassembled through continuous washing with running water and plants were dissected into root, leaves and stolon. Minimum, maximum and average temperatures were recorded in the period and presented mean values of $17.5,39.5$ and $28.5^{\circ} \mathrm{C}$, respectively.

Root volume $(\mathrm{mL})$ was determined with the use of a volumetric beaker, and the dry mass of root, leaves and stolons per pot through drying in an oven at $65{ }^{\circ} \mathrm{C}$ for 72 hours. Nodes were separated, dried in an oven for determination of dry mass and counted.

For the study of growth, one stolon per pot was tagged with colored tapes, totaling four replications per treatment. Measurements were taken at every two days, during the experimental period. On each stolon, the following characteristics were evaluated: appearance of leaf apex and total exposure of the leaf, stolon length, number, length and width of the folioles that constitute the leaf; and number of senescing leaves. With these data, the morphogenetic (leaf appearance rate, phyllochron and stolon elongation rate) and structural (number of green leaves, number of senescing leaves, total number of leaves and stolons, final width and length of leaflets and stolon) characteristics were calculated. These variables were calculated as follows:

Leaf appearance rate (LAR): the number of leaves (petioles) emerged on the tagged stolons of each pot divided by the number of evaluation days (leaves/day);

Phyllochron: the inverse of LAR (days/leaf);

Stolon appearance rate (SAR; $\mathrm{mm} /$ day): final stolon length $(\mathrm{cm})$ minus initial stolon length $(\mathrm{cm})$, divided by the interval of days between the measurements.

Total number of green leaves per pot (TNGL/pot): count of the number of expanding and expanded leaves per pot;

Total number of senescing leaves per pot (TNSL/pot): count of the number of senescing leaves per pot; 
Final width and length of leaflets $(\mathrm{cm})$ : average of the measure of four leaflets of completely expanded leaves;

Final stolon length (FSL; cm): difference between initial and final measures of the stolon in the experimental period;

Number of stolons per pot (NSP): count of the number of stolons per pot at the end of the experimental period.

The data were submitted to multiple regression analysis, with selection of a linear model whose coefficients were evaluated by the t test, adopting $\alpha=0.05$. Initially, one equation with linear, quadratic and cubic effects was tested, in addition to effects of factors water regime and nitrogen doses. For the model chosen, the coefficient of determination $\left(\mathrm{R}^{2}\right)$ was presented for evaluation of model adequacy.

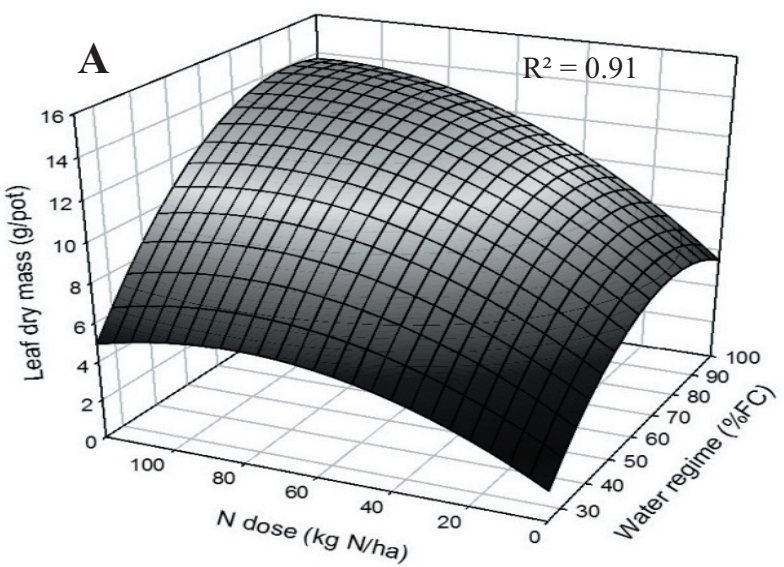

$\mathrm{LDM}=-5.23+0.089 \mathrm{~N}-0.00062 * \mathrm{~N}^{2}+0.34 \mathrm{FC}-0.0022 * \mathrm{FC}^{2}+0.00054 * \mathrm{NFC}$

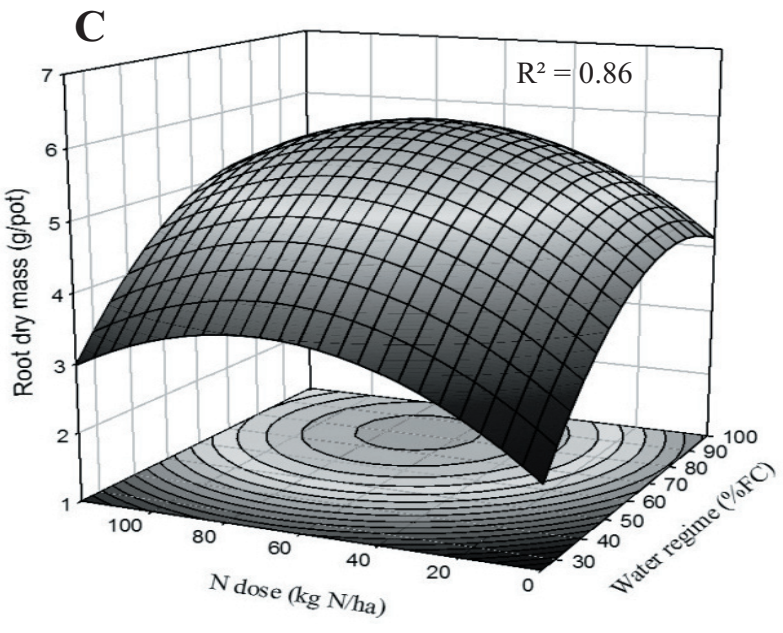

$\mathrm{RDM}=-0.26+0.042 \mathrm{~N}-0.0029 * \mathrm{~N}^{2}+0.11 \mathrm{FC}-0.0007 * \mathrm{FC}^{2}$

\section{Results and Discussion}

Leaf dry mass (LDM) and stolon dry mass (SDM) varied $(\mathrm{P}<0.05)$ with effect of the interaction between nitrogen $(\mathrm{N})$ doses and water regime (WR) (Figures 1A and 1B). In this case, the elevation in leaf dry mass occurred because of the increase in $\mathrm{N}$ and WR, with $14.0 \mathrm{~g}$ of LDM estimated per pot, which corresponds to $2800 \mathrm{~kg} \mathrm{LDM} / \mathrm{ha}$, with application of $115 \mathrm{~kg} \mathrm{~N} /$ ha and $90 \%$ of field capacity. Such results indicate the positive influence of $\mathrm{N}$ in leaf dry mass production and of the water requirements of the plant in order to maintain growth and utilization of this nutrient. The highest SDM production (12.5 g/pot or $2500 \mathrm{~kg} / \mathrm{ha}$ ) was verified for the dose of $120 \mathrm{~kg} \mathrm{~N}$ and $100 \%$ of field capacity.

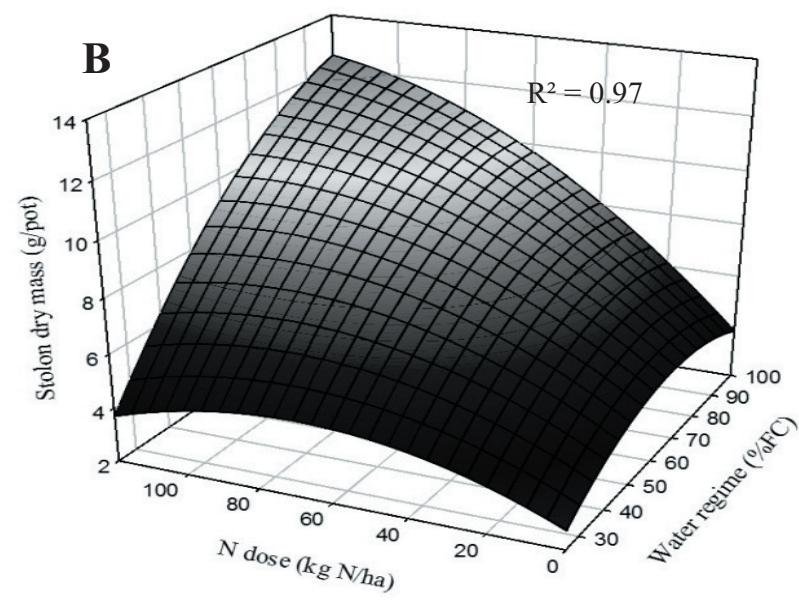

$\mathrm{SDM}=-0.17+0.038 \mathrm{~N}-0.00043 * \mathrm{~N}^{2}+0.14 \mathrm{FC}-0.00099 \mathrm{FC}^{2}+0.00085 * \mathrm{NFC}$

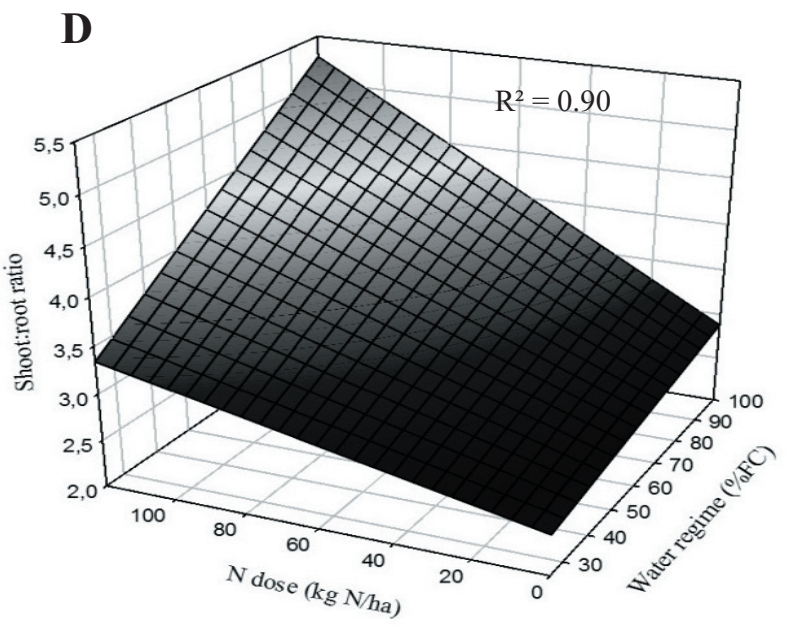

$\mathrm{SR}=2.27+0.0035 \mathrm{~N}+0.0061 \mathrm{FC}+0.00016 * \mathrm{NFC}$

$\mathrm{P}<0.05$

LDM - leaf dry mass; SDM - stolon dry mass; RDM - root dry mass; SR - shoot:root ratio; FC - field capacity; N - nitrogen; WR - water regime.

Figure 1 - Effect of nitrogen dose and water regime in percentage of field capacity on leaf dry mass (A), stolon dry mass (B), root dry mass (C) and shoot:root ratio (D) of Arachis pintoi cv. Belmonte. 
According to Lopes et al. (2011), under ideal hydrologic conditions and stimulated by nitrogen fertilization, forage plants usually express their potential for forage production, achieving greater yields. This could be observed in these results, once at a WR inferior to $50 \%$ of field capacity, LDM and SDM were not affected by the $\mathrm{N}$ doses, demonstrating the importance of water for proper utilization of this nutrient.

Root dry mass $(\mathrm{RDM})$ varied quadratically $(\mathrm{P}<0.05)$ with effect of nitrogen $(\mathrm{N})$ doses and water regime (WR), with no interaction between the treatments for this variable. Under favorable hydrologic conditions (above $75 \%$ of field capacity), there was decrease in root growth for the doses from 90 to $120 \mathrm{~kg} \mathrm{~N} / \mathrm{ha}$, probably because there was no need for root growth due to the high availability of nitrogen and water in the soil.

Root dry matter was close to $6.0 \mathrm{~g}(1200 \mathrm{~kg} / \mathrm{ha})$ with $70 \mathrm{~kg} \mathrm{~N}$ and $80 \%$ of field capacity (Figure 1C). The root volume (RV) responded linearly to the water regime and quadratically to $\mathrm{N}$, according to the equation $\mathrm{RV}=19.69$ $+0.22 * * \mathrm{~N}-0.0021 * * \mathrm{~N}^{2}+0.27 * \mathrm{FC}$ (*significant by the $\mathrm{t}$ test $\mathrm{P}<0.01 ; * * \mathrm{P}<0.05$ ), with $\mathrm{R}^{2}=0.77$, with no interaction between the treatments.

Because of the quadratic effect of RV as a response to $\mathrm{N}$, the greatest volume $(52.0 \mathrm{~mL})$ was found with $50 \mathrm{~kg}$ $\mathrm{N} / \mathrm{ha}$ and $100 \%$ of field capacity; there was reduction in this volume for doses higher than $50 \mathrm{~kg} \mathrm{~N} / \mathrm{ha}$ in any water regime, demonstrating the negative interference of $\mathrm{N}$ when present at high doses. According to Bélanger et al. (1992), the increase in $\mathrm{N}$ usually elevates the growth of the root shoot rather than of the root, which is expected when there is no deficiency of nutrient or water.

Comparing LDM, SDM and RDM, the shoot benefited from the presence of high doses of $\mathrm{N}$ when the hydrologic conditions were favorable, while in the roots this behavior was not observed. Such results are possibly explained by the high nutrient and water availability in the soil, allowing for the growth of the shoot without need for root expansion for an efficient absorption.

Shoot/root ratio (S:R) responded positively to the interaction between $\mathrm{N}$ and $\mathrm{WR}(\mathrm{P}<0.05)$, with highest ratio (5:1) at the application of $120 \mathrm{~kg} \mathrm{~N} / \mathrm{ha}$ and $100 \%$ of the field capacity, corroborating the data of LDM, SDM and RDM, because under these conditions it presented greater production of aerial portion in relation to the root (Figure 1D).

There was no statistical difference for the nodulation data. However, at a WR inferior to $50 \%$ of the field capacity, the application of $120 \mathrm{~kg} \mathrm{~N} / \mathrm{ha}$ resulted in lower number and dry weight of nodules in the roots of the legume. On the other hand, doses between 40 and $80 \mathrm{~kg} \mathrm{~N} / \mathrm{ha}$ did not interfere with production of nodes, presenting similar values to those in absence of N. Evaluating the interference of nitrogen in productivity and nodulation of soy, Mendes et al. (2008) concluded that in spite of promoting more crop yield, the application of $200 \mathrm{~kg} \mathrm{~N} / \mathrm{ha}$ impaired nodulation.

The total number of green leaves per pot (TNGL/pot) responded quadratically $(\mathrm{P}<0.05)$ to $\mathrm{N}$ and WR separately; the highest value, 364 leaves/pot (72,800,000 leaves/ha), was obtained with application of $80 \mathrm{~N} / \mathrm{ha}$ and $80 \%$ of field capacity, whereas the plants which did not receive nitrogen and were under lower WR ( $25 \%$ of the field capacity) showed lower value (25 leaves/pot, corresponding to $5,000,000$ leaves/ha) (Figure 2A). Thus, the number of green leaves is affected by external (nutritional and hydrologic) factors, especially by the greater water availability in the soil, once it is of paramount importance for the metabolism and displacement of nutrients in the plant (Lopes et al., 2011).

The total number of senescing leaves per pot (TNSL/ pot) was affected $(\mathrm{P}<0.05)$ by the interaction between the levels of $\mathrm{N}$ and $\mathrm{WR}$, with maximum value (78 leaves/pot or 15,600,000 leaves/ha) estimated for the application of $120 \mathrm{~kg} \mathrm{~N} / \mathrm{ha}$ and WR of $25 \%$ of field capacity (Figure 2B). The water regime between 70 and $100 \%$ of field capacity, at any $\mathrm{N}$ dose, resulted in lower TNSL/pot, which demonstrates that water availability is essential for the maintenance of the green area. In addition to genetic, climatic and environmental factors, the senescence process of forages is accelerated with elevation in the nitrogen doses, reducing leaf lifespan by accelerating its life cycle (Silva, 2006).

The response of leaf appearance rate (LAR) to the interaction of $\mathrm{N}$ doses and $\mathrm{WR}(\mathrm{P}<0.05)$ resulted, according to the equation, in a value close to 1.2 leaves/day at $120 \mathrm{~kg} \mathrm{~N} / \mathrm{ha}$ and $90 \%$ of field capacity, and minimum of 0.9 leaves/day at the same $\mathrm{N}$ level and $25 \%$ of field capacity (Figure 3A). Overall, fertilization with up to $15 \mathrm{~kg} \mathrm{~N} / \mathrm{ha}$, as well as WR below $50 \%$ of field capacity affected LAR negatively, confirming the positive effect of nitrogen fertilization on this variable and emphasizing the necessity of appropriate hydrologic conditions for there to be availability and utilization of this nutrient by the plant.

According to Silva (2006), N is important in the reduction of the time for appearance of two successful leaves, increasing the production of new cells and having a positive impact on the number of leaves per plant, which is of great importance, given that leaves represent the part of the plant with highest nutritional value. The lack of water in the soil promotes stomatal closure so as to reduce water loss through transpiration, thus decreasing the absorption of water and nutrients by the roots (Taiz \& Zeiger, 2009). 
The longest time spent for the formation of a new leaf, known as phyllochron, as a response to the interaction of $\mathrm{N}$ and WR $(\mathrm{P}<0.05)$ was found at the combination of $25 \%$ of field capacity and $120 \mathrm{~kg} \mathrm{~N} /$ ha (6.6 days/leaf), whereas the lowest value was verified with WR of $85 \%$ of field capacity and $115 \mathrm{~kg} \mathrm{~N} /$ ha (4.6 days/leaf) (Figure 3B).

The final leaflet width (FLW) showed linear effect $(\mathrm{P}<0.05)$ of $\mathrm{N}$ according to the equation $\mathrm{FLW}=1.26+$ $0.0014 * \mathrm{~N}$ (*significant by the $\mathrm{t}$ test $\mathrm{P}<0.01$ ), with $\mathrm{R}^{2}=0.56$.
The smallest width found was estimated at $1.3 \mathrm{~cm}$ in the absence of $\mathrm{N}$ and the greatest, of $1.4 \mathrm{~cm}$, with application of $120 \mathrm{~kg} \mathrm{~N} /$ ha. For final leaflet length (FLL), linear effect $(\mathrm{P}<0.05)$ and quadratic effect of WR were observed, according to the equation $\mathrm{FLL}=2.49+0.0014 * \mathrm{~N}$ $-0.0109 * \mathrm{FC}+0.000088 * \mathrm{FC}^{2}$ (*significant by the $\mathrm{t}$ test $\mathrm{P}<0.05$ ), with $\mathrm{R}^{2}=0.49$. The greatest FLL was estimated at $2.4 \mathrm{~cm}$ under conditions of $100 \%$ of field capacity and $120 \mathrm{~kg} \mathrm{~N} / \mathrm{ha}$, and the lowest at around $2.1 \mathrm{~cm}$ with $60 \%$

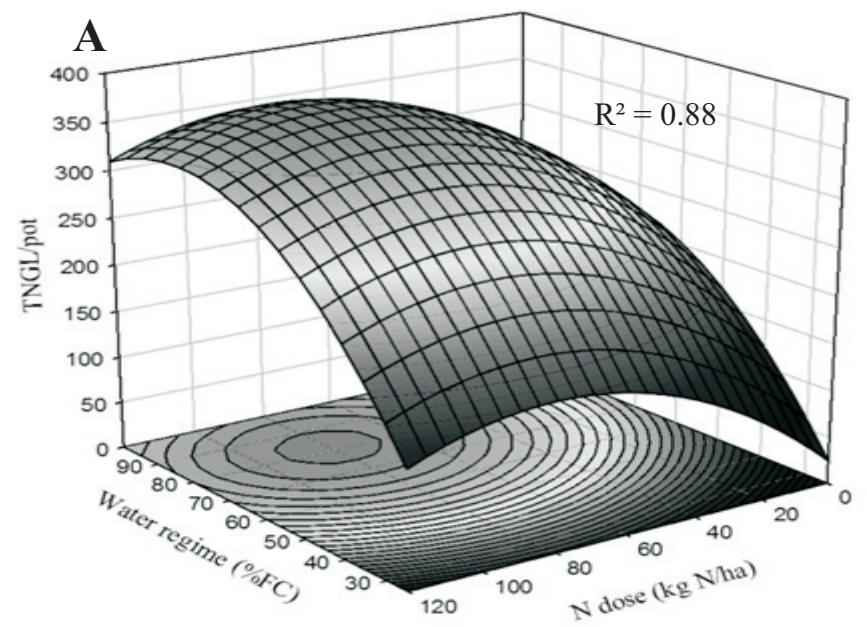

$\mathrm{TNGL}=-199.56+3.28 \mathrm{~N}-0.21 * \mathrm{~N}^{2}+10.58 \mathrm{FC}-0.065 * \mathrm{FC}^{2}$

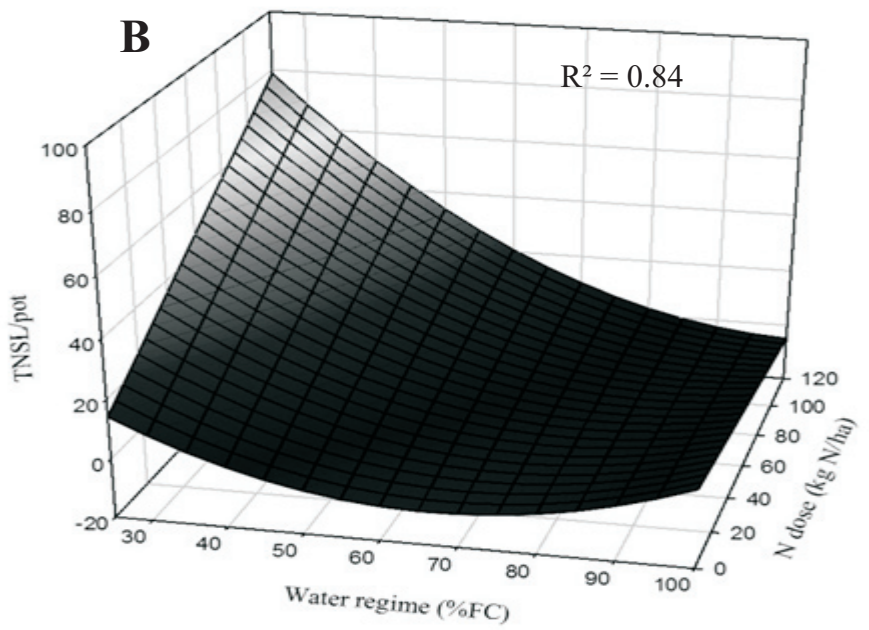

$\mathrm{TNSL}=50.53+0.75 \mathrm{~N}-1.79 \mathrm{FC}+0.014 * \mathrm{FC}-0.0084 \mathrm{NFC}$

$* \mathrm{P}<0.05$.

TNGL - total number of green leaves; TNSL - total number of senescing leaves; N - nitrogen; WR - water regime; FC - field capacity.

Figure 2 - Effect of nitrogen dose and water regime and percentage of field capacity on total number of green leaves per pot (A) and total number of senescing leaves per pot (B) of Arachis pintoi cv. Belmonte.

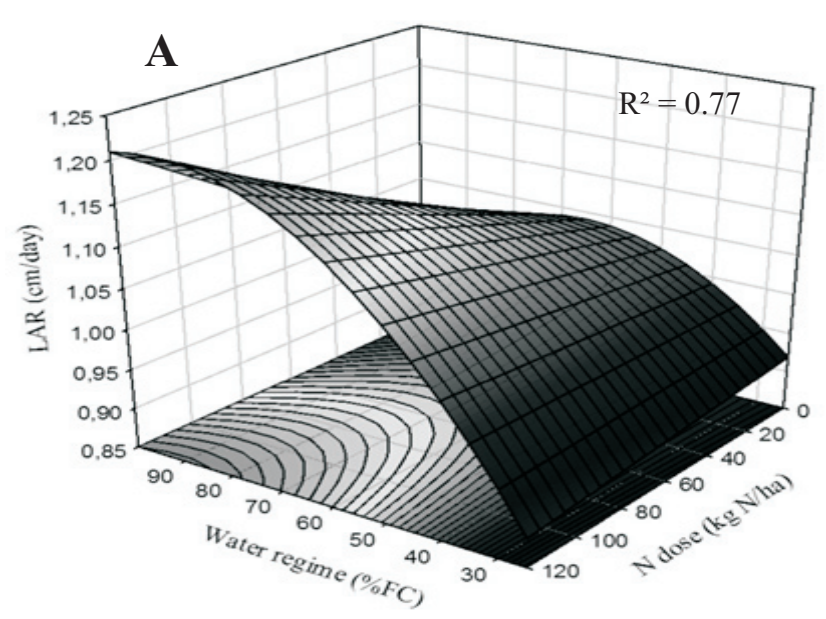

$\mathrm{LAR}=0.72-0.001 \mathrm{~N}+0.0097 \mathrm{FC}-0.000073 * \mathrm{FC}^{2}+0.000032 * \mathrm{NFC}$

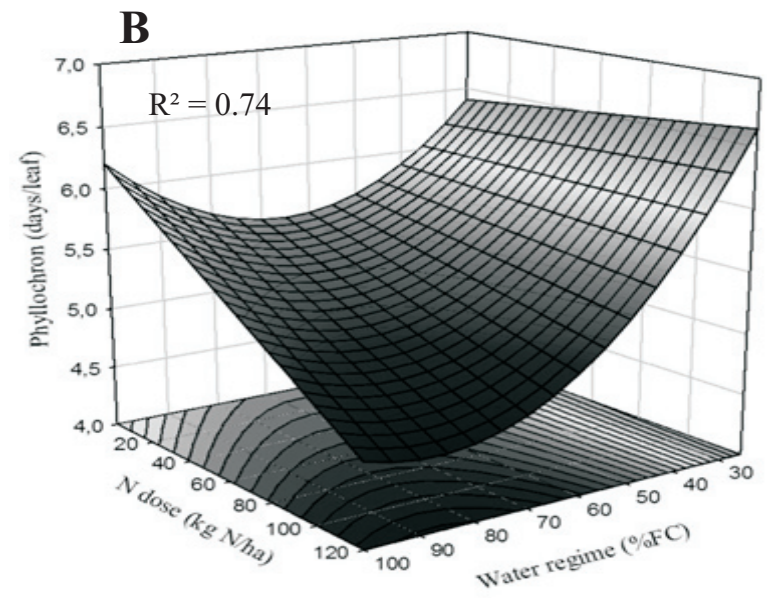

Phyllochron $=7.79+0.0069 \mathrm{FC}+0.00053^{*} \mathrm{FC}^{2}+0.00017 * \mathrm{NFC}$

$* \mathrm{P}<0.05$

LAR - leaf appearance rate; FC - field capacity; N - nitrogen; WR - water regime.

Figure 3 - Effect of the nitrogen dose and water regime in percentage of field capacity on leaf appearance rate (A) and phyllochron (B) of Arachis pintoi cv. Belmonte. 
of field capacity and absence of N. The nitrogen supply promoted positive increase in the leaf size, contributing with production of leaf dry mass (Figure 1A). At the same time, this positive effect of $\mathrm{N}$ on the total number of green leaves (TNGL), leaf dry mass and final width and length of the leaf along with the water deficiency favored the increase of leaf senescence, probably by accelerating the vegetative cycle, as explained and suggested for the total number of green leaves.

Stolon elongation rate (SER) was only influenced by WR $(\mathrm{P}<0.05)$, according to the equation SER $=0.24+0.012 * \mathrm{FC}$ ( ${ }^{*}$ significant by the $t$ test $\mathrm{P}<0.01$ ), with $\mathrm{R}^{2}=0.57$, presenting an estimated value of $0.5 \mathrm{~cm} /$ day under $25 \%$ of field capacity and $1.4 \mathrm{~cm} /$ day at $100 \%$ field capacity. In spite of this, the final stolon length (FSL) showed quadratic effect $(\mathrm{P}<0.05)$ for the $\mathrm{N}$ doses, according to the equation: $\mathrm{FSL}=31.81+$ $0.22 * * \mathrm{~N}-0.0016 * * \mathrm{~N}^{2}+0.19 * \mathrm{FC}$ (*significant by the $\mathrm{t}$ test $\mathrm{P}<0.01 ; * * \mathrm{P}<0.05$ ), with $\mathrm{R}^{2}=0.53$. Thus, the highest FSL was recorded with the application of $70 \mathrm{~kg} \mathrm{~N} / \mathrm{ha}$ and $100 \%$ of field capacity, reaching an estimated value of $58.2 \mathrm{~cm}$.

The response of the number of stolons per pot (NSP) was quadratic $(\mathrm{P}<0.05)$ both for the $\mathrm{N}$ doses and $\mathrm{WR}$, according to the equation NSP $=7.94+0.095^{*} \mathrm{~N}-0.00046^{* *} \mathrm{~N}^{2}+$ $0.34 * \mathrm{FC}-0.0025 * \mathrm{FC}^{2}$ (*significant by the $\mathrm{t}$ test $\mathrm{P}<0.01$; $* * \mathrm{P}<0.05)$, with $\mathrm{R}^{2}=0.66$. The highest NSP (24.5 stolons/ pot or 4,900,000 stolons/ha) was obtained with application of $105 \mathrm{~kg} \mathrm{~N} / \mathrm{ha}$ and with $70 \%$ of field capacity. The increase in the number of stolons per plant promotes greater soil coverage by the forage plant, contributing to the diminution of soil degradation, by reducing the exposure to the impacts of rain and sun (Silva, 2006).

According to Valentim et al. (2003), the lateral growth of stolons is a characteristic of great influence on the speed of establishment of forage peanut, for determining the capacity of colonization of the area by the plants. Likewise, the number of leaves present on the plant is important for its establishment, since it relates with the potential of biomass accumulation (Silva, 2006).

Under favorable hydrologic conditions (70 to $100 \%$ of field capacity), $\mathrm{N}$ positively influences the development of the shoot of Arachis pintoi cv. Belmonte at 85 days of growth, and the doses of 40 and $80 \mathrm{~kg} \mathrm{~N} / \mathrm{ha}$ are the most efficient ones. In the roots, higher doses (90 to $120 \mathrm{~kg} \mathrm{~N} / \mathrm{ha}$ ) of nitrogen reduce their growth.

\section{Conclusions}

When applied during the period of establishment of forage peanut and under low water availability (water regimes lower than $50 \%$ of field capacity), nitrogen fertilization has positive effects, once it promotes more growth during the establishment and maintenance of the shoot of the plants during the period of water stress.

\section{References}

ALVAREZ V., V.H.; RIBEIRO, A.C. Calagem. In: COMISSÃO DE FERTILIDADE DO SOLO DO ESTADO DE MINAS GERAIS (CFSMG). Recomendações para o uso de corretivos e fertilizantes em Minas Gerais. $5^{a}$ aproximação. Viçosa, MG, 1999. p.41-60.

BÉLANGER, G.; GASTAL, F.; WAREMBOURG, F. The effects of nitrogen fertilization and the growing season on carbon portioning in a sward of tall fescue. Annals of Botany, v.70, p.239-244, 1992.

LOPES, W.B.; CARVALHO, G.G.P.; PATÊS, N.M.S. et al. Dinâmica, produção e qualidade da Brachiaria brizantha submetida a regime hídrico e adubação nitrogenada. Revista Brasileira Saúde e Produção Animal, v.12, n.1, p.43-58, 2011.

MENDES, I.C.; REIS JUNIOR, F.B.; HUNGRIA, M. et al. Adubação nitrogenada suplementar tardia em soja cultivada em latossolos do cerrado. Pesquisa Agropecuária Brasileira, v.43, n.8, p.1053-1060, 2008.

MIRANDA, C.H.B.; VIEIRA, A.; CADISCH, G. Determinação da fixação biológica de nitrogênio no amendoim forrageiro (Arachis spp.) por intermédio da abundância natural de ${ }^{15} \mathrm{~N}$. Revista Brasileira de Zootecnia, v.32, n.6, p.1859-1865, 2003.

PIZARRO, E.A.; RINCÓN, A. Regional experience with forage Arachis in South America. In: KERRIDGE, P.C.; HARDY, B. (Eds.) Biology and agronomy of forage Arachis. Cali, Colômbia: CIAT, 1994. p.144-157.

POMPEU, R.C.F.F.; CÂNDIDO, M.J.D.; LOPES, M.N. et al. Características morfofisiológicas do capim-aruana sob diferentes doses de nitrogênio. Revista Brasileira Saúde e Produção Animal, v.11, n.4, p.1187-1210, 2010.

RAMOS, A.K.B.; BARCELLOS, A.O.; FENANDES, F.D. Gênero Arachis. In: FONSECA, D.M.; MARTUSCELLO, J.A. (Eds.) Plantas forrageiras. Viçosa, MG: UFV, 2010. p.250-293.

SILVA, C.C.F. Morfogênese e produção de braquiárias submetidas a diferentes doses de nitrogênio. 2006. 72f. Dissertação (Mestrado em Zootecnia) - Universidade Estadual do Sudoeste da Bahia, Itapetinga.

SILVA, S.C. Desafios e perspectivas para a pesquisa e uso de leguminosas em pastagens tropicais: uma reflexão. In: ENCONTRO SOBRE LEGUMINOSAS: DESAFIO E PERSPECTIVAS, 2., 2008, Nova Odessa. Anais... Nova Odessa, 2008. p.163.

TAIZ, L.; ZEIGER, E. Fisiologia vegetal. 4.ed. Porto Alegre: Artmed, 2009. p.95-102.

VALENTIM, J.F.; ANDRADE, C.M.S.; MENDONÇA, H.A. et al. Velocidade de estabelecimento de Acessos de Amendoim Forrageiro na Amazônia Ocidental. Revista Brasileira de Zootecnia, v.32, n.6, p.1569-1577, 2003. 